This is an electronic version of an article published as: Meijer Drees, L. (2010). Indian hospitals and Aboriginal nurses: Canada and Alaska. Canadian Bulletin of Medical History / Bulletin canadien d'histoire de la médecine, 27(1), 139-161.

Canadian Bulletin of Medical History / Bulletin canadien d'histoire de la médecine is published by the Canadian Society for the History of Medicine and is available online at:

http://www.cbmh.ca/index.php/cbmh/index.

This article is available at: http://www.cbmh.ca/index.php/cbmh/article/view/1345/1315. 


\title{
Indian Hospitals and Aboriginal Nurses: Canada and Alaska
}

\author{
LAURIE MEIJER DREES
}

\begin{abstract}
Between 1945 and the early 1970s, both Indian Health Services in Canada (IHS), and the Alaska Native Health Service (ANS) initiated programs and activities aimed at recruiting and training nurses/nurses aides from Canadian and Alaskan Native communities. In Alaska, the Mt. Edgecumbe Hospital in Sitka acted as a training facility for Alaska Native nurses' aides, while in Canada, the Charles Camsell Hospital served a similar function. These initiatives occurred prior to the devolution of health care to Aboriginal communities. The histories of these two hospitals provide a comparative opportunity to reveal themes related to the history of Aboriginal nurse training and Aboriginal health policies in the north. The paper outlines the structure and function of two main hospitals within the Indian Health and Alaska Native Health Services, discusses the historic training, and role of Aboriginal nurses and caregivers within those systems using both archival and oral history sources.
\end{abstract}

Keywords. Aboriginal nurse, tuberculosis, Mt. Edgecumbe, Indian Health Services

Résumé. Entre 1945 et le début des années 1970, les Services de santé aux Autochtones (IHS) du Canada et le Alaska Native Health Service (ANS) ont lancé des programmes et des activités visant à recruter et à former des infirmières et des aides-infirmières issues des communautés autochtones du Canada et de l'Alaska. Le Mt. Edgecumbe Hospital de Sitka en Alaska et le Charles Camsell Hospital au Canada sont devenus à cette fin des lieux de formation pour aides-infirmières. Ces initiatives sont survenues avant la dévolution des services de santé aux communautés autochtones. L'histoire de ces deux hôpitaux permet de mener une étude comparative des thèmes reliés à l'histoire des infirmières autochtones et des politiques sanitaires visant les Amérindiens dans le Nord. À l'aide de documents d'archives et d'une enquête orale, l'article examine l'organisation et le rôle de deux hôpitaux importants au sein des services de santé dédiés aux autochtones du Canada et de l'Alaska, et se penche sur la formation et le rôle des infirmières et donneurs de soins.

Laurie Meijer Drees, PhD, First Nations Studies Department, Vancouver Island University. 
Mots-clés. Infirmière autochtone, Tuberculose, Mt. Edgecumbe, Services de santé aux amérindiens

\section{INTRODUCTION}

Between 1945 and the early 1970s, the Indian Health Services in Canada (IHS) and the Alaska Native Health Service (ANS) initiated programs and activities aimed at recruiting and training nurses/nurses aides from Canadian and Alaskan Native communities. Their goal: to address the tuberculosis epidemic in Aboriginal communities. In Sitka, Alaska, the Mount Edgecumbe Hospital acted as a training facility for Alaska Native nurses' aides, while in Canada, the Charles Camsell Indian Hospital served a similar function. For decades, Aboriginal communities, particularly those in remote and northern locations, were devastated by tuberculosis. In Alaska in 1950, for example, nearly $90 \%$ of Native Alaskan 10 -year-olds in northern, interior, and western Alaska were infected with the bacillus. ${ }^{1}$ Not surprisingly, in Alaska and northwestern Canada TB directly spurred the mid-century formation of formal, state-operated health care systems in Aboriginal communities and the training of Aboriginal personnel to staff those systems.

This paper takes a comparative approach to describing-and interpreting - the impact of the IHS and the ANS between 1945 and the late 1960s. Specifically, it examines the workings of two main tuberculosis hospitals: the Charles Camsell Indian Hospital in Edmonton, Alberta and the Mount Edgecumbe Hospital in Sitka, Alaska. On the one hand, the two institutions and their associated services and staff were very similar in this period. First, both operated in very similar cultural and geographic contexts: the western subarctic and arctic, featuring many small and remote Aboriginal communities. Second, both hospitals were founded to deal with the TB crisis in those communities. Third, the hospitals were very similar structurally and functionally; both operated under the auspices of the federal Departments of National Health, not Indian Affairs. Overall, the impact of these hospitals was noteworthy. Both supported some degree of emergence of a formal, western-style health care culture within Aboriginal communities; in addition, they had a powerful hand in the relocation of Aboriginal peoples, their reeducation, as well as influencing positively or negatively the creation of Aboriginal health care "para-professionals" accredited within that formal health care system.

Yet, a compelling qualitative difference emerges from the comparison of the IHS and ANS hospitals. The American service did much to support Aboriginal communities in the self-delivery and self-administra- 
tion of their own health programs, while the Canadian system entrenched a culture of health care delivery that was a highly centralized hierarchy of decision making, and operated in Canada's northwest without noteworthy Aboriginal participation. In Alaska, both the state and federal governments were proactive and co-operative in their attempts to educate and train Alaska Native communities in participating withand working in-formal health care systems. In Canada, Aboriginal peoples primarily played service roles in health care delivery, and the administration and delivery of health care services was not devolved to Aboriginal communities. In fact, in the 1950s and 1960s, the Canadian IHS offered communities little beyond non-Native nursing services and hospital care.

This central historic difference between ANS and IHS is related to contemporary challenges that face Canada's Aboriginal peoples. The lack of Aboriginal presence as workers and administrators in Canada's health care system has been noteworthy and continues to this day, with significant social and political consequences. ${ }^{2}$ Although some authors attribute the lack of Aboriginal participation to the poverty and low rate of formal education in most (and especially northern) Canadian Aboriginal communities, ${ }^{3}$ it is contended here that the histories of government policies and actions towards the establishment of health care systems appropriate to Aboriginal peoples, as indicated by the history of the Indian hospitals, were also a factor. These histories reveal that valuable opportunities to create such systems with Aboriginal peoples were missed. This conclusion is also supported by evidence presented to the Royal Commission on Aboriginal Peoples' round table on Aboriginal Health, where Aboriginal leaders expressed their ongoing frustration with lack of government consultation and institutional inertia around attempts to develop health programming in Native communities. ${ }^{4}$ In Alaska, the opportunities to link Aboriginal peoples to health care delivery were capitalized upon, and today Alaska Native peoples are well represented in the state's formal health care systems as administrators, nurses, doctors and other professionals.

Comparative research on government policy is challenging under the best of circumstances. In this case, comparing American federal and state policies on Aboriginal health to Canadian initiatives is difficult because little secondary literature exists on the subject. Excellent research has been completed into the history of both the Alaska Native Service (later the Alaska Native Health Service), and Canada's Indian Health Services. ${ }^{5}$ Much of this literature focuses on government attempts to control health crises in Aboriginal communities. Aboriginal perspectives on the history of formal health care in Aboriginal communities are, to date, scarce.

In addition to the published literature related to the subject, this paper is based on archival and oral history research conducted between 2000 
and 2004. The Alaska State Archives in Juneau, Alaska, contains important documents related to the Alaska Native Service as well as the Alaska Department of Health and Alaska Board of Health. The National Archives for the Pacific Alaska Region in Anchorage, Alaska were a further source for information on the American Indian Health Service and the Alaska Native Service. In addition to this archival research, oral history interviews on the Alaska Native Service and its training initiatives aimed at Native Alaskans were conducted with Dr. Walter Johnson, a pioneer physician in the area of community health aide training and with several staff members of the Mount Edgecumbe Hospital in Sitka, Alaska. Information on Canada's Indian Health Services derives both from federal government documents housed at the National Archives of Canada in Ottawa and from oral history interviews with former staff of the Charles Camsell Indian Hospital. The papers related to the Camsell Hospital are currently held in the Provincial Archives of Alberta.

The research presented here is far from complete. First and foremost, it represents an attempt to provide an overview of trends in government-sponsored health care in both Alaska and northwestern Canada as reflected through the operation of hospital facilities. It is hoped that this comparison will successfully highlight and accentuate themes that emerge from each respective set of histories. A deeper investigation of Aboriginal perspectives on the impact of IHS and ANS services on Aboriginal communities would be most valuable to understanding the complex history of health care delivery to, and reception in, the north.

\section{MOUNT EDGECUMBE HOSPITAL: STRUCTURE AND FUNCTION}

Mount Edgecumbe is a 3,467 foot extinct volcano located on Kruzof Island, near the town Sitka, on the coast of Southeast Alaska. In the shadow of this great geologic feature sits the Mt. Edgecumbe Hospital and a former Alaska Native Service boarding school. Built up out of the buildings of a former US Naval Base located on a series of small islands in Sitka Sound, the Mt. Edgecumbe facilities were transferred to the Bureau of Indian Affairs, Alaska Native Service branch in 1946 to provide a boarding school and TB sanatorium for Alaska's indigenous population. Although an Alaska Native Service boarding school existed in Eklutna, near Anchorage, and an ANS sanatorium operated in Skagway, these facilities had deteriorated beyond repair. Spurred on by the lobbying of Alaskan Native leaders, including Andrew P. Hope and Mark Hope Sr. of the Alaska Native Brotherhood, as well as the territorial Commissioner of Health, C. Earl Albrecht, the ANS sought to update and centralize these institutions by moving their services to the decommissioned military site at Sitka. ${ }^{6}$ Other ANS boarding schools and hos- 
pitals were also in operation around the state before World War II, including hospitals at Bethel, Barrow, Juneau, and Unalaska to name a few; however, the Mt. Edgecumbe facilities would quickly be established as the largest and most significant in the state. ${ }^{7}$

In 1946, the Mt. Edgecumbe school and hospital facilities were reconstructed out of the remains of the worn-out military buildings which had seen heavy usage during the war. Despite the fact that existing housing for staff and construction workers on the islands were dilapidated, utilities were in need of renovation and materials were difficult to obtain, extensive renovations were launched in the fall and early winter of that year. As a result of the unexpected closure of the ANS sanatorium at Skagway because of severe winter weather, the Mt. Edgecumbe Hospital was hastily opened in February 1947 to receive 91 TB patients arriving on the S.S. North Sea after a 16-hour voyage. In a similar unanticipated move, the school was opened that same month with the arrival of over 300 Alaska Native students from other schools in the state because of the decay of existing schools. ${ }^{8}$ Within six months, the abandoned military base had been transformed into a bustling ANS facility. The old Navy hospital formed the orthopedic section of the facility (for treatment of bone TB) with 65 beds, while an outlying Army hospital building was quickly established as the TB sanatorium (for pulmonary TB) known as the Alice Island Sanatorium, with 140 beds. ${ }^{9}$ The majority of the patients were children, ranging in age from a few months to 15 or 16 years old. In 1950 , as a result of the need for additional beds and the advancement of TB treatment through surgery required better surgical facilities, a new highrise hospital was built on site. Mt. Edgecumbe became known as offering the "gold standard" for TB treatment in the state. ${ }^{10}$

Figure 1

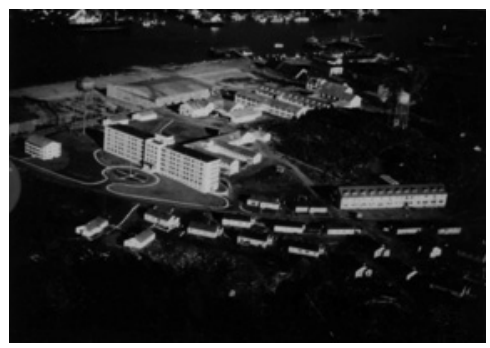

Mount Edgecumbe Hospital and School, 1950s, featuring the new highrise hospital built in 1950. Source: Marjorie Ward private collection.

Technically speaking, as an ANS facility, the Mt. Edgecumbe Hospital operated under the jurisdiction of the federal Bureau of Indian Affairs. In reality, it operated in very close co-operation with the territorial Department of Health, the US Public Health Service (USPHS), 
Figure 2

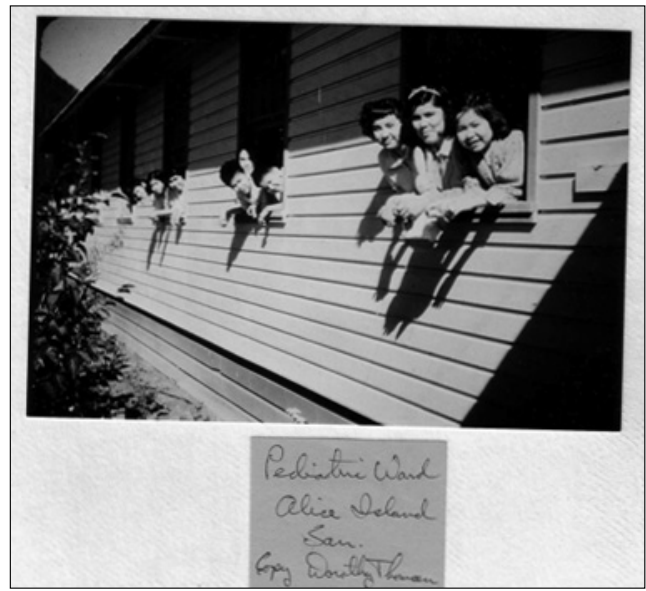

TB Ward on Alice Island, 1950s. Source: Marjorie Ward private collection.

the Alaska Tuberculosis Association, and the Alaska Crippled Children's Association, all of which contributed personnel to the administration and delivery of health care services in the hospital. ${ }^{11}$ For example, the territorial Department of Health contributed the professional services of Dr. Phillip H. Moore as orthopedic surgeon in 1947, while two Occupational Therapy staff were paid for by the Alaska Crippled Children's Association and the Alaska Tuberculosis Association. The central commitment of the ANS to offering hospital service in this time period was reflected in the fact that, in 1955, more than half the ANS budget was devoted to hospital operations. ${ }^{12}$

The close co-operation of these various agencies was a result not only of the region's geographic isolation from the Lower 48, but also of the need to share communication, transportation, and scarce resources in the struggle against TB. From the outset of its operations in 1931, the ANS contracted a great deal of its public health nursing services through the Alaska Department of Health. In 1946, the ADH held the view that, "The removal of racial barriers in nursing service makes possible a more unified community public health program, eliminates unavoidable duplications in service, and reduces the total cost of nursing service." 13 To this end, by 1955 the Department of Health and ANS jointly operated 11 nursing stations, as well as Mobile Health Units, including the specially outfitted ship M/S Hygiene, and the Mobile Truck Unit, both used to test for TB in remote coastal and inland communities. ${ }^{14}$ Co-operation between the state and the ANS was an attempt to deliver health care services effectively and in all communities, Native or non-Native. 
Despite the sharing of health care services and resources between ANS and the ADH, a 1954 federal investigation into the effectiveness of Aboriginal health service in the territory-conducted by former US Surgeon General Dr. Thomas Parran, revealed the ANS had not served Alaska Native peoples sufficiently. Pressure for sharing in the delivery of health services between ANS and the ADH was intensified that year when the "Parran Report" recommended the consolidation of ANS and ADH services. ${ }^{15}$ As a result, in 1954 control over the ANS was transferred from the Bureau of Indian Affairs to the federal Public Health Service, based on the belief that TB control was a priority overriding all jurisdictional considerations. ${ }^{16}$ It was also hoped that having the ANS under the Public Health Service would increase the number of medical personnel available for Native health care since the Public Health Service offered better career opportunities for physicians than the BIA. ${ }^{17}$ From 1955 on, health services would be contracted by the USPHS to the ADH to be delivered as ANS programs.

Perhaps a most significant change that emerged from the repositioning of the ANS under the USPHS, and contracted through the ADH, was that from 1955 onwards, the USPHS adopted a philosophy of administration aimed at decentralizing responsibility for its programs directly to outlying ANS hospitals in the state, giving those areas a great deal of local control, and positioning the hospitals as service centers. ${ }^{18} \mathrm{Mt}$. Edgecumbe Hospital, as one of the larger hospitals in the state, could thus sponsor and support community development in health care delivery.

This locally oriented perspective towards health care delivery was far from radical within the state. In the 1950s, C. Earl Albrecht, the Commissioner of Health for Alaska's ADH, regularly supported initiatives empowering communities to take responsibility for improving health care services in their areas. Since ADH was now contracted for the delivery of ANS services, Albrecht's personal philosophy favouring community control and involvement, influenced the approach taken to Alaska Native health care. The Alaska Board of Health, the executive body for the ADH also supported notions of Alaska Native self-determination in health, and when the ANS shift took place in 1954, they actively emphasized that, "The concurrence of the Indians, Aleuts, and Eskimos in a transfer of facilities and operations to the Alaska Department of Health should be a must ..." and that it "would appear feasible and desirable for having the Natives participate in the planning of the program and for adjusting services and operations to the needs and attitudes of the Natives." 19 In keeping with these views, the ADH had already launched two community-based health care initiatives with the ANS: the sanitation aide program and the chemotherapy aide program in $1954 .{ }^{20}$ Both of these programs involved the training of Alaska Native individuals within their community as health care specialists; they were trained in either 
community sanitation or local delivery of TB antibiotics to ambulatory patients.

Changes in policy at the Mt. Edgecumbe Hospital predated the shift away from the BIA. By the early 1950s, the Hospital had already begun implementing measures to train Alaska Native peoples as health care providers: they pioneered a Practical Nurse (PN) and a dental assistant program, both launched in 1951 with the first classes running in January 1952..$^{21}$ The program was based on a year-long curriculum, and within a year and a half, 75 students successfully completed the program. According to contemporary reports and photographs, the PN course was attended by both men and women representing a variety of cultures in Alaska: "The lineup by races in one of the classes, which is typical of those participating in the program thus far, is 16 Eskimos, four Indians and one Aleut." 22 Within the first year of the program, graduates were also immediately employed at other ANS hospitals around the state. For example, four Mt. Edgecumbe graduates were quickly placed on the payroll at the ANS hospital in Anchorage. ${ }^{23}$

Figure 3

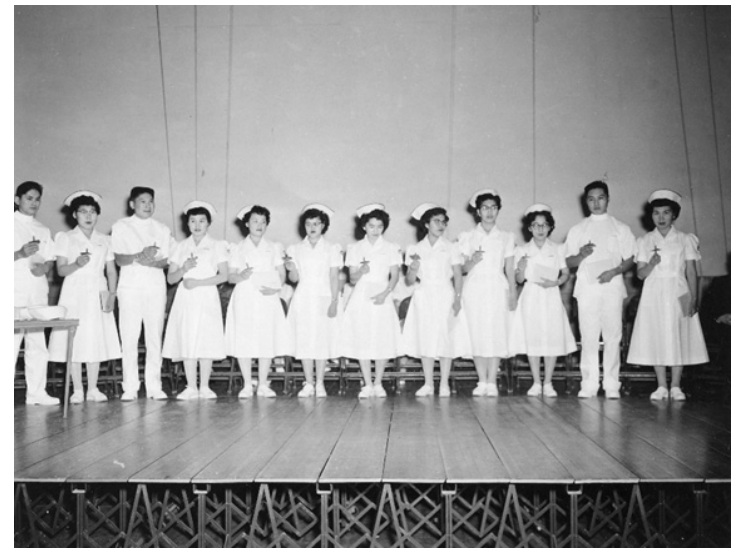

Mt. Edgecumbe Practical Nurses Program Grads, 1950s. Source: \#84-051-110N, Alaska Nurses Association Collection, Archives, University of Alaska at Fairbanks.

Students entered the PN training program in a variety of ways. Some were inspired by their teachers, while others wanted to help their own people. Most became interested in the training and profession as a result of their experience at the Mt. Edgecumbe Boarding School. Initially, the students were required to have completed grade eight for acceptance into the program, although many had tenth grade standing, or had graduated. Other students arrived at Mt. Edgecumbe as tubercular patients and upon their convalescence and completion of their schooling, went on to enroll in the PN program. Mary Jane Simpson from the 
Alaska Native community of Holy Cross in interior Alaska, for example, arrived at Mt. Edgecumbe as a patient suffering from bone TB. Upon her discharge in 1956, she returned to school and began working as a nurses' aide in the hospital by 1959.24 In turn, Gemma Gaudio, originally from the Hooper Bay community, dreamt of being a nurse after her experience as a tubercular patient as a young teenager in Bellingham, Washington and because of her admiration for the public health nurse in her village. Upon her return to her home community, Gaudio resisted her parents' efforts to encourage her marriage and boldly announced her goal: "I wanted to go to nursing school so bad and I said to my mother, I'm not gonna get married until I'm 21!" Her father replied, "If she wants to become a nurse, go let her become a nurse." She travelled to Mt. Edgecumbe to take the year-long PN program. Upon graduation, she took a position in the ANS hospital at Bethel, in the Yukon delta, where Gaudio worked with other Mt. Edgecumbe graduates. ${ }^{25}$ She continued her work there even after her marriage.

The curriculum for the PN program was developed by Virginia Murphy, director of the program for the US Department of Health, and Effie Graham, assistant director, and represented the first nurse training program in Alaska. Effie Graham recalled in 1976 that students were taught the subjects of home economics, anatomy, physiology and were also given hands-on instruction in clinical work at the Mt. Edgecumbe Hospital. In addition, students also travelled to Tacoma, Washington State for practicum training, specifically in obstetrics, and were accompanied by their teachers while out of the territory. Later this field experience was taken in Anchorage.

According to Graham, the students received "a very high quality" of teaching although many were challenged by the "confining and disciplined" nature of the program, and of the work itself. Indeed, the program represented a process of exposing the students to a vocational culture of formal health care service that they may not have been familiar with. Vera Marvin, Alutiiq from Kodiak Island and a member of the PN graduating class of '59, recalled that the program "was excellent-the best," and that she worked hard to train herself after she had finished. ${ }^{26}$ Many of the PNs worked in Mt. Edgecumbe after graduation, and in the late 1950s it was common to have one PN on each ward. ${ }^{27}$ Other graduates worked at the hospital briefly only to return to their home villages and later assumed the role of village Health Aide when that formal position became available in the 1960s. ${ }^{28}$ The PN program at Mt. Edgecumbe was discontinued in 1961, and Alaska Native students were encouraged to pursue Registered Nurse training at the ANS hospital in Anchorage after that date. ${ }^{29}$

In addition to the PN training program at Mt. Edgecumbe, the hospital also employed "Ward Aides," many of them Alaskan Native. Ward Aides (also known as Home Nursing Aides) assisted with the myriad of 
labour-intensive tasks associated with the nursing care of bedridden TB patients at the time. For example, children with bone TB were often confined to their beds with body casts, or strapped into metal frames to encourage the healing of their fragile and damaged bones. These patients had to be turned regularly, bathed, entertained, fed and comforted. Corrine Brown, originally from Kodiak Island and a graduate of Mt. Edgecumbe High School in 1955, completed the one-semester Home Nursing course through the hospital, and worked on the wards helping feed, bathe, and keep an eye on the often "mischievous" patients. She spent 34 years in service at the hospital in various capacities, first as a Ward Aide, then in the surgery, and finally in the hospital supply service. She noted that although many of the high school graduates from the boarding school returned home to the Native villages, many also found rewarding employment and training at the hospital, and remained in Sitka for the rest of their careers, integrating into Sitka's Alaska Native community which was diverse because of the hospital's presence. ${ }^{30}$

With the many patients and the limited number of registered nurses, the Ward Aides were invaluable assistants to the nurses. According to Marlys Tedin and Marjorie Ward, two non-Native RNs who worked in the orthopedic section of Mt.Edgecumbe Hospital during the 1950s, the Ward Aides and the PNs were critically important, also, for translating and understanding the children and adult patients' cultural needs. In some cases, the Ward Aides and PNs had to educate the RNs as to which patients could be housed together in the same room, and which could not, and help nurses with some degree of informal cultural "sensitivity training." 31

Beyond training Alaska Native students as PNs and ward aides, the Mt. Edgecumbe Hospital also contributed to the education of Alaska Native peoples as health care providers through programs targeting patients. In the mid-1950s, short workshops were organized in the hospital "to prepare patients hospitalized for an extended period to serve as health teachers to their families and neighbours, and in some instances to serve as aides to the Public Health Nurse when they return to their respective villages." ${ }^{32}$ Since patients suffering with TB were often subject to lengthy stays in hospital, in some cases for years at a time, it was hoped the health education program would assist them in taking on new roles within their home communities when they returned by passing along their basic knowledge of scientific public health practices. This particular initiative on the part of Mt. Edgecumbe staff represented an informal approach to delivering and encouraging formal health training for Alaska Native peoples.

Finally, the Mt. Edgecumbe Hospital employed Alaska Native peoples in many support roles throughout the facility. Aboriginal people held positions as maintenance workers, cooks, cleaners, and orderlies, often 
travelling to Sitka from outlying villages and taking these positions because family members were in the hospital with TB or because they themselves were infected. ${ }^{33}$ All of these roles were important for patient care, but also contributed to the promotion of a formal health care culture in the Alaska Native community of Sitka and beyond.

In summary, the Mt. Edgecumbe Hospital functioned as a hub of health care delivery and training for Alaska Native people from across the state. On the one hand, it encouraged individuals to train and work as practical nurses within the hospital facility, as well as in outlying hospitals and, later, Alaska Native villages. In this way Mt. Edgecumbe Hospital facilitated the development of a formalized vocational health care culture that worked to the advantage of the hospital itself, addressed the TB crisis, and also aided in the dispersal of that culture to the general Alaska Native population. On the other hand, the hospital also cultivated an informal culture of health care through its function as an employer of many Alaska Native peoples in service positions throughout the institution-firstly as ward aides and through the direct health education of patients, and secondly as cooks, cleaners, orderlies and maintenance workers. As a formal health care centre, the hospital inevitably led to the relocation of Alaska Native families, for both health and employment reasons; many long-term patients remained in the Sitka area after their recovery, and some chose to stay for work. Finally, the hospital further integrated itself into the Alaska Native community through its own non-Native staff, particularly RNs who, not infrequently, married into the Alaska Native community during their tenure at Mt. Edgecumbe.

It should be emphasized that much of the activity related to the training and hiring practices at Mt. Edgecumbe reflected the greater territorial and federal context of the time. The agenda in that period was that Alaska Native peoples be given more self-control over the formal health care systems within their communities. In addition, at the same time Mt. Edgecumbe was at the peak of its operations between 1947 and the late 1960s, the state and federal governments worked together to promote the training of chemotherapy aides and sanitation aides in rural Alaska Native villages in the early 1950s (formalized in 1957), and the creation of a formal Community Health Aide pilot program in 1964/65, regularized in $1968 .{ }^{34}$ In the words of Amos Alter of the Alaska Department of Health, founder and early promoter of community oriented health delivery initiatives, "We were thinking, how do you create an awareness [about health and hygiene] among the village people? We thought if they were fully aware of what needed to be done they would do it, probably ..." These initiatives were very well received in the Native villages, and were supported by the ANS hospital network. ${ }^{35}$ According to Dr. Walter Johnson, USPHS physician and another pioneer of commu- 
nity-based health care delivery in Alaska in the 1950s, "it was apparent that the only long-term workers would be indigenous people comfortable in a rural setting with an understanding of local cultural values ..."36 Even the Alaska Department of Health acknowledged and promoted the notion that "No one is better qualified to take an environmental health program to a native community than a trained local native of village choice," in reference to the significance of creating locally based health programs. ${ }^{37}$

\section{CHARLES CAMSELL INDIAN HOSPITAL: STRUCTURE AND FUNCTION}

The Charles Camsell Indian Hospital had its origins in remarkably similar circumstances as the Mt. Edgecumbe Hospital. Although located in a large, southern urban centre, the hospital was created to address the TB crisis in northern and western Canada. Much like Alaska, northwestern and western arctic Canadian Aboriginal communities were devastated by TB, suffering infection rates higher than in eastern and central Canada. ${ }^{38}$ In 1946, the general incidence of TB in registered Indian communities was reported by the Canada's Indian Health Services, using very limited data, to be $579: 100,000-15$ times that of the non-Native population. TB remained the leading cause of mortality among Indians and the Inuit until 1952. ${ }^{39}$ The severity of TB occurrence was linked at the time not only to lack of resistance on the part of Aboriginal peoples, but also to "...ignorance and filth, poor housing and unbalanced diet ...." 40

In 1945, the federal government had already taken steps to address growing concerns about the Crown's responsibility for Indian and Inuit health in Canada. That year it transferred the Indian Health Services Division from the Department of Indian Affairs to the newly established Department of National Health and Welfare. Like Alaska's ANS, the IHS was perceived to belong under a federal department concerned with public health, not Indian Affairs. Despite the aim of Canada's IHS to address public health questions in Aboriginal communities, it did so on what it perceived as a "temporary" and charitable basis. First and foremost, the IHS sought "to provide a complete health service for these [Status Indian and Inuit] peoples," based on a moral, rather than legal, imperative. More directly, "Canada's Indian Health Service...has arisen, not from legislative obligation, but rather as a moral undertaking to succor the less fortunate and to raise the standard of health generally." $41 \mathrm{~A}$ second goal was to "improve assimilation" of Indian peoples by supporting provisions against ill-health and thereby eventually encouraging their economic independence. ${ }^{42}$ Their aim was also to "correct" the "incorrect" health practices of the past in Indigenous communities: "It is not as if we were merely trying to replace ignorance with correct atti- 
tudes and knowledge. We are trying to introduce new attitudes and practices to people who already have strong feelings and traditions about sickness and its treatment, however erroneous these may be." 43

Furthermore, in response to the TB crisis, and as a result of growing public pressure to address the issue for public health reasons, the federal government acted upon the recommendations of the "Advisory Committee for the Control and Prevention of Tuberculosis among the Indians" that additional hospitals for TB treatment be made available. ${ }^{44}$ As a result, in June 1946 the Edmonton Military Hospital was transferred from the Department of National Defense to the Department of National Health and Welfare for the purpose of establishing a TB treatment facility for Indian and Inuit patients. Originally an old Jesuit College refurbished by the American military during the Second World War, the facility was characterized by a central three storey brick building. Behind it lay a maze of redwood barrack buildings connected to the main building via a long hallway nicknamed the "Burma Road." 45 It featured a 400bed capacity. That same summer the hospital was renamed the Charles Camsell Indian Hospital (after a Deputy Minister of Mines and Resources), and opened to the first Indian and Inuit patients.

Figure 4

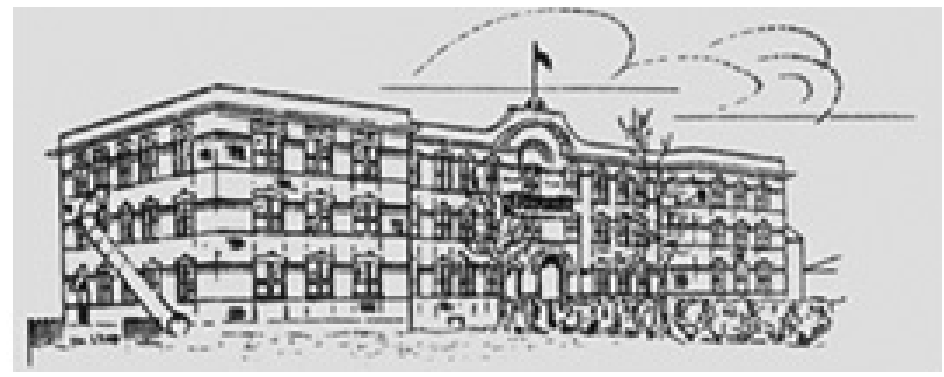

The Charles Camsell Indian Hospital, 1947 Main Building. Source: Charles Camsell Pictorial Review, Department of Indian Affairs, 1957.

Much like the Mt. Edgecumbe Hospital, the Camsell was the largest IHS hospital in the region, and was considered the most significant. It hosted expertise and facilities unavailable in the middle and far northern regions of western Canada, where surgery and treatment facilities were less developed, and staff very limited in numbers. For the next three decades it was the most prominent institution involved in treating Inuit and registered Indian peoples from the Yukon, Northwest Territories, Northern British Columbia and Alberta (whose combined Indian/Inuit population numbered about 25,700 ) for TB. ${ }^{46}$ Children and adults alike were treated at the Camsell. In 1965-67 the hospital was rebuilt and enlarged into a fully "modern" facility. 
Unlike the Alaskan hospital, however, the Camsell only had connection to regional or local provincial health authorities after 1958, and then only minimally ${ }^{47}$ In addition, it was only marginally involved in efforts to train Aboriginal communities to self-administer health care services. Although the official position of the Minister of the Department of Health and Welfare in regards to the IHS and questions of health care was "The government does not want to be paternalistic, to spoon-feed either group. It aims rather at putting the Indians and Eskimos in a position to maintain themselves," 48 only a handful of sporadic initiatives were taken to place the Indian and Inuit populations in a position where they could self-administer even the most basic formal health care program. Although minor practical nurse training courses were held inconsistently in other IHS hospitals, such as the Coqualeetza Indian Hospital in British Columbia, as a main hospital Camsell showed little leadership in this area.

In the Camsell Hospital, one of the efforts to train Indian and Inuit individuals in health care delivery included a nurses' aide training initiative. Official evidence for this training is scant at this time, but photographs taken in the Camsell and published in 1956 show a class of Indian, Inuit, and non-Native students receiving instruction to become aides. The program was never formalized, however, and it was probably similar to efforts made in other IHS hospitals in western Canada where young women were trained in basic bed-making, cleaning, and bedside nursing on an individual or small group basis. ${ }^{49}$ Other, non-IHS, aide training programs existed in Alberta at the time, and some Native women took advantage of this education and subsequently worked at the Camsell Hospital. ${ }^{50}$

As in Alaska, former patients of the Camsell Hospital were also hired to work in non-medical support posts in the hospital. Many took positions as cooks and kitchen helpers, or in cleaning and maintenance. For example, Harriet Buffalo, a patient from 1948-1949, returned to work in the hospital kitchens upon her recovery: "In 1953, I was employed at the hospital to work in the ward kitchens. I helped serve meals to the Eskimo and Indian patients, young and old. I appreciated the work and enjoyed it." 51 Others were trained in technical positions as x-ray technicians, laboratory assistants, and orderlies. This technical training was done through an informal Rehabilitation Program launched in 1955 to train young people deemed too debilitated to return home to their Native communities upon remission of their TB. These former patients were transferred out of the hospital to two local Edmonton homes where they were taught basic skills that would allow them to work in a variety of settings, including a hospital or nursing clinic, but not necessarily back in their home communities. Discontinued in 1961, no records of this program remain beyond documented oral histories of the instructors. ${ }^{52}$ 
Figure 5

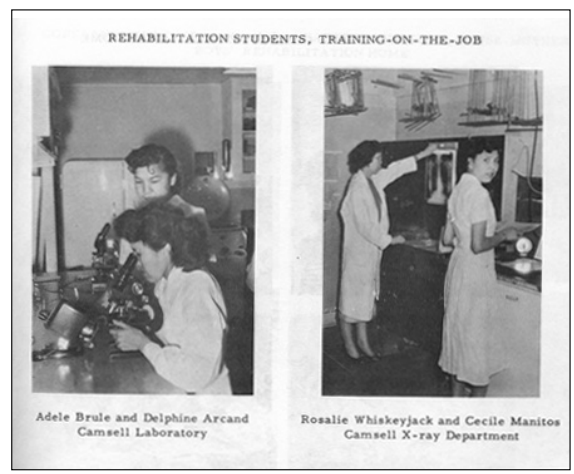

Aboriginal technical staff working in the Charles Camsell Indian Hospital in 1957. Source: Charles Camsell Pictorial Review, Department of Indian Affairs, 1957.

Despite the dearth of IHS sponsored training opportunities in nursing related work, Aboriginal Registered Nurses were hired and worked in the Charles Camsell Hospital from an early date. These women did not obtain their training through the IHS; rather, they pursued their nursing education at established nurse training programs in non-IHS hospitals. This situation was similar to that at Mt. Edgecumbe where some Alaska Native nurses had attained RN accreditation outside the territory. At the Camsell, Kathleen A. J. Steinhauer-Anderson of Saddle Lake First Nation was one such individual. As a young woman she visited the hospital as a guest at the many social functions held for patients, family and visitors at the Camsell: "There was no Native Friendship Centre in those days, of course, so for us, the Camsell became the nearest thing to it." Initially, she worked for several weeks as a ward aide at the hospital. She then received her RN training at the nearby Lamont Hospital on her own initiative, graduating in 1954. From there, she took up work as an RN at the Camsell, only to be taken aback by some of the circumstances she encountered: "After I graduated with my RN designation, I went to work in the Indian hospital in Edmonton. That was the Camsell, and I started on the pediatric ward. The conditions there were pretty bad. The babies were all dried with the same towel! I had to petition hard to get separate towels and towel racks for each baby patient. Some things were just improper." ${ }^{53}$ She also recalled being confronted with racism among the nursing staff, but developed friendships with many of the, mostly immigrant, maintenance staff employed in the facility. ${ }^{54}$

Although data is scarce and unreliable on this front, the number of Aboriginal people employed by the IHS in health service roles appears low, not just at the Camsell, but across Canada in 1952. In that year, the Minister responsible for IHS announced to Parliament that "We now 
have about 212 Indians in our service, although the number fluctuates. I fully agree...that we ought to make every endeavor to have as many of the native population as possible serve in this capacity. We have taken steps to get young girls to go into nursing training and have encouraged them in every way. Our success in that regard is not what I would like it to be." 55 Despite his lament, few formalized training opportunities existed within the IHS itself, and the Service continued to rely on outside agencies to provide this education to Aboriginal peoples. This situation contrasted with the ANS system, which offered PN and RN training within its own hospitals.

Until the 1960s, IHS kept health care delivery and education in the hands of its almost exclusively non-Native staff, especially the IHS field nurse. For example, in 1948/49, Aboriginal communities were still not empowered to be trained to self-administer or educate their people. Instead, community education meant "Indian Health Services medical officers and nurses infiltrate into Homemaker Clubs and other women's organizations, giving instructional chats and showing health films," 56 or "to improve health standards by demonstration, example and gentle pressure." 57 It seems the attitude was paternalistic, aiming to "show" rather than to "empower."

This attitude may have been rooted in the federal government's political position that it was under no legal obligation to provide health care to Indian and Inuit people. To this end, in 1962 the IHS was reconfigured within the DNHW to be subsumed within a larger entity known as the Medical Services, although "Indian Health Service" remained as the label many in administration worked with. The federal government argued consistently that "The existence of the Service is evidence of the recognition by the State of a moral, rather than a legal, responsibility towards a group whose economy would not otherwise permit them adequately to care for themselves...It functions primarily as a public health service... It is prepared to hand back these functions to the home, the local community and the province when these agencies exhibit the will and the resources to take them over." 58

At the same time, the attitude that Aboriginal communities were not ready to be involved in their own health care, either because of lack of interest or will or ability, was also pervasive among nursing staff and administrators. According to the IHS in 1966, "Regardless of the cause or causes, the problem still remains of how to get the Indians and Eskimos to accept the truths of modern hygiene ... Telling has not worked ... Action has proved better than information." ${ }^{99}$ In the view of Dr. W. G. Brown, Editor of the Canadian Journal of Public Health in 1966, "There is no question that efforts to have public health practices accepted by our Indian and Eskimo citizens in remote communities have been marked more by failure than success." 60 
It was in the 1960s, later than in Alaska, that the IHS did make efforts to involve Aboriginal communities in health care programs by launching Sanitation Aide and Community Health Aide training in 1960 and 1961, respectively. Although these initiatives did not involve the Camsell Hospital directly, they did reflect a context and gradual effort by the Canadian federal government to bring health related training to communities. Much the same as in Alaska, the Aide programs invited Indian communities to recommend individuals for training, and the curriculum included first aid, nutrition, and sanitation information for the male students, while the female students were taught public health nursing subjects. The first of these programs were run in northern Manitoba.

The primary short-term goals for these programs were "to encourage the participation of local people in health activities of their communities by involving them in initiating, planning and carrying out those programs; to give professional health workers an opportunity to become more effective by providing a link with the local community ..." 61 These were merely short-term goals, however. It was still presumed at this time that the professional workers were non-Native and that local training would remain basic. The context of these initiatives was different from that of Alaska. Unlike in the American territory, there was little explicit and direct intention to have communities service their own members. In fact, the Community Health Aide worker position quickly became problematic and by 1972 a formal Task Force was created to study solutions because "... Despite progress in many respects, the role of the Community Health Worker became confused and frustrating, particularly in the case of more recent graduates" whom the training program was unable to support. ${ }^{62}$ Eventually the program was restructured and reconfigured in 1974 to train Community Health Representatives (CHR), who would receive continuing education and more support in their work. By the 1970s, the federal government began an active retreat from offering treatment services in the area of Indian health.63

In summary, Canada's IHS and its Charles Camsell Indian Hospital provided significant health care to northwestern Canadian Aboriginal communities, both Indian and Inuit, at a time when these communities suffered epidemics of TB. The Camsell Hospital was one of the largest specialized TB and Indian health hospitals in Canada, and as such it contributed a great deal to the improvement of Indian health and health care. In addition, it educated its patient population to take on service roles in the health care system in the south. This action, in turn, encouraged the relocation of many of their patients away from their home communities. Yet, unlike in Alaska, the hospital only contributed in a minor way to the extension of formal health care education and culture to either local or northern Aboriginal communities. There was some nursing/ward aide, and technical support worker training offered to 
Aboriginal people in the hospital, yet none of it was formal or accredited. Throughout the period between 1945 and the late 1960, IHS continued to rely almost exclusively on non-Native Canadian nurses-and even nurses recruited from the UK-to carry out its services, both in the Camsell and in its field stations. Until the late 1960s, much, if not all, of the Indian and Inuit health policy and decision-making was made by IHS administrators. This situation was unlike Alaska, where Alaska Native people were consulted and their political organizations had a hand in policy formulation.

\section{CONCLUSIONS}

Comparing the workings of two state-sponsored institutions in two different countries, the Mt. Edgecumbe Hospital of Sitka, Alaska and the Charles Camsell Indian Hospital of Edmonton, Alberta reveals significant yet subtle themes in the history of Indian health care and the involvement of Aboriginal peoples in formal health care services prior to the 1970s. Although, at first glance, the institutions appear very similar in their structure and function-both institutions were founded and operated under federal jurisdiction to address the TB epidemics ravaging northern Canadian and Alaskan Aboriginal communities-the tenor and intent of their efforts were different. In Alaska, the efforts of the state and federal health authorities were to export formal health services to Alaska Native communities in such a manner that those communities could self-administer and self-direct those services as soon as possible. To this end, the Mt. Edgecumbe Hospital offered support and education that allowed Alaska Native peoples opportunities to gain training in formal health care and return home with that knowledge. In contrast, the Charles Camsell Indian Hospital, a similarly sized institution as the Mt. Edgecumbe facility treating Inuit and Indian patients alike, was less committed to bringing formal health care services to Aboriginal communities through the direct training and involvement of Aboriginal people themselves. It offered only minor ward aide/nursing aide training, and did little to encourage or recruit Aboriginal people into formal health care roles. As a result, it appears Canada's IHS did little to support the extension of a formal health care culture to northwestern Aboriginal communities beyond the hard efforts of their non-Native field staff.

The subtle yet noteworthy differences between the Camsell and Edgecumbe hospitals might have their origins in the fact that Canada's IHS was limited by its political philosophy that it was not obligated to provide health care for Indian and Inuit people. Officials in Canada were not keen to devolve programs to Aboriginal communities, while in Alaska an attitude of "cooperation" and self-determination was far more evident. The political position of the Canadian officials may have been 
bolstered by the fact that the Camsell Hospital was located in an urban centre near many other hospitals and medical facilities offering varying degrees of para-medical training. By and large, however, it is clear that Canada's approach to health care education for Indian and Inuit people was more limited than in Alaska. Hard statistics on the numbers of Aboriginal graduates from either the ANS or IHS programs are very thin, but the indirect evidence from oral history, photographic sources and the underlying attitudes of health care officials themselves suggest that the Canadian system did little to support either the formal or informal dissemination of the culture of formal health care in Aboriginal communities before the late 1960s. The consequences of this historic Canadian position can still be perceived today.

\section{NOTES}

1 Liz Ruskin, "TB's harsh toll," Anchorage Daily News, 30 July 2000, p. A-6, p. A-1 and A-6. TB is a disease with many faces and a significant history in the Canadian and American north. In the first half of the 20th century it was also a primary factor in the cause of death in northern North American Aboriginal communities. Caused by a small bacterium, mycobacterium tuberculosis, the disease is commonly associated with the development of small tumors in the lungs, eventually causing hemorrhaging of the lung tissue and killing the infected person if left untreated. The disease, however, can also spread to other organ systems within the body, including the heart, bones, joints, brain, gastrointestinal and lymphatic systems. If unchecked, TB is difficult to control; not all those infected with the bacterium display symptoms associated with the disease. Often, individuals infected with the bacterium merely act as carriers of the agent, spreading the bacterium to others through coughing and sneezing droplets containing the bacterium onto others unknowingly. Although the BCG vaccine was developed to increase human immunity to TB in 1906, until the introduction of antibiotics such as streptomycin, para-aminosalicylic (PAS) and isoniazid (INH) into the treatment regime for TB after World War II, prognosis for infected individuals was often poor as TB debilitated-and even caused the death of-patients.

2 Canada, Royal Commission on Aboriginal Peoples, The Path to Healing: Report of the National Round Table on Aboriginal Health and Social Issues (Ottawa: Supply and Services, 1993). In this volume see also "Appendix 1 -Health Science Advocacy Programs for Aboriginal Students at Four Canadian Universities," p. 189-210, which provides statistics on numbers of Aboriginal peoples pursuing careers in the health sciences. These numbers are very low and indicate high drop-out rates for students in the health sciences.

3 James B. Waldram, Ann Herring, and T. Kue Young, Aboriginal Health in Canada: Historical, Cultural and Epidemiological Perspectives (Toronto: University of Toronto Press, 1995), p.153, 161-163, 164. The authors note poverty and ignorance are historically described as root causes of Indian health issues. In describing perceptions of government agents relating to Aboriginal health and health care in the 1960s, they write, "As the years passed, however, it became increasingly evident that the poor socio-economic conditions of the Indians, including sanitation and education, were to a large extent responsible for their relatively poor health" (p. 164). A review of Indian health services conducted for the Medical Services Branch, as reported in the Booz-Allen report of 1969, suggested that lack of education was significant in hampering Indian 
participation in health care (p. 195). Even the self-determination initiatives of the early 1980s, such as the Community Health Demonstration Program, ran on the premise that Aboriginal communities were not ready to be self-determining in health matters because of lack of funding and training (p. 236-37). Waldram, Herring and Young further suggest that one of the first initiatives to train Aboriginal care-givers, the Community Health Representative program of the 1960s, "smacked of tokenism, since at the time there were no efforts to train Aboriginal people for the more advanced medical positions" (p. 253). Such cultural/structural explanations and views have permeated both the literature on Aboriginal health and government policy in this area. See also Dianne Longboat, "Pathways to a Dream: Professional Education in the Health Sciences," in Canada, Royal Commission on Aboriginal Peoples, The Path to Healing: Report of the National Round Table on Aboriginal Health and Social Issues, (Ottawa: Supply and Services, 1993), p. 171-88. Longboat outlines poverty and lack of education as related to the dearth of Aboriginal health care professionals. These ideas are summarized and supported in Terry Wotherspoon and Vic Satzewich, First Nations: Race, Class and Gender Relations (Scarborough: Nelson Canada, 1993), p. 147-79.

4 Canada, Royal Commission on Aboriginal Peoples, The Path to Healing (1993), p. 20-21.

5 For Canada, see Waldram, Herring, and Young, Aboriginal Health in Canada; T. Kue Young, Health Care and Cultural Change: The Indian Experience in the Central Subarctic (Toronto: University of Toronto Press, 1988); Mary Ellen Kelm, Colonizing Bodies: Aboriginal Health and Healing in British Columbia, 1900-1950 (Vancouver: UBC Press, 1999); Pat S. Grygier, A Long Way From Home: The Tuberculosis Epidemic among the Inuit (Montreal: McGill-Queen's University Press, 1994); and G. Graham-Cumming, "Health of the Original Canadians, 1867-1967," Medical Services Journal of Canada, 23, 2 (1967): 11566. For the American and Alaskan content, see Robert Fortuine, "Health Care and the Alaska Native: Some Historical Perspectives," Polar Notes, 14 (1975): 1-42; Philip Nice with Walter Johnson, The Alaska Health Aide Program: A Tradition of Helping Ourselves (Philip Nice, 1998), p. 1-62; Abraham B. Bergman, David C. Grossman and Angela M. Erdrich et al., "A Political History of the Indian Health Service," The Milbank Quarterly, 77, 4 (1999): 571-604; Stephen J. Kunitz, "The History and Politics of US Health Care Policy for American Indians and Alaskan Natives," American Journal of Public Health, 86, 10 (October 1996): 1464-73; Penelope M. Cordes, "The Federal Government-Native American Relationship and the Indian Health Service in Alaska," Alaska Medicine, 32, 2 (April/May/June 1990): 67-71; S. S. R. Haraldson, "Evaluation of Alaskan Native Health Service: Alternative Approaches to Meeting Basic Health Needs," in Roy J. Shephard and S. Itoh, eds., Circumpolar Health, Proceedings of the 3rd International Symposium, Yellowknife, NWT (Ottawa: Health and Welfare Canada, 1974), p. 559-64.

6 Peter Metcalfe, Gumboot Determination: the Story of the South East Regional Health Consortium (Juneau: South East regional Health Consortium, 2005), p. 31.

7 Elva R. Scott, "Health History of the Upper Yukon," (unpublished manuscript, Eagle City, Alaska, 1983) in University of Alaska-Fairbanks, Alaska Nurses' Association Collection, Series 13, Box 32, File 513, p. 179-180. Scott provides a list of hospitals in 1940. See also description of Mount Edgecumbe facilities in Bob Bruxman, "Mount Edgecumbe," (unpublished manuscript, Marge Tedin private collection, 14 January 1949).

8 Bruxman, "Mount Edgecumbe," p. 3-4.

9 Bruxman, "Mount Edgecumbe," p. 12 and 13. Also, University of Alaska-Fairbanks, Oral History Archives, Tape H96-32-02, Marjorie Ward in interview by Dr. Walter Johnson with Marjorie Ward, Marlys Tedin, and Dorothy Thomsen in Sitka, AK, 18 April 1996.

10 University of Alaska-Fairbanks, Oral History Archives, Tape H96-32-02, Marlys Tedin in interview by Dr. Walter Johnson with Marjorie Ward, Marlys Tedin, and Dorothy Thomsen in Sitka, AK, 18 April 1996. 
11 Bruxman, "Mount Edgecumbe," p. 12.

12 Alaska Health Survey Team, Alaska's Health: A Survey Report to the U.S. Department of the Interior, by Thomas Parran and others (Pittsburgh: University of Pittsburgh, Graduate School of Public Health, 1954) p. iv-4.

13 C. Earl Albrecht, Alaska Commissioner of Health, Alaska Department of Health Biennial Report for the period 1 July 1946 to 30 June 1948 (Juneau: Alaska Department of Health, 1948) p. 35.

14 Alaska Health Survey Team, Alaska's Health, p. iv-6. Also, C. Earl Albrecht, Alaska Commissioner of Health, Alaska Department of Health Biennial Report for the period 1 July 1946 to 30 June 1948 (Juneau: Alaska Department of Health, 1948) p. 35.

15 Alaska Health Survey Team, Alaska's Health, p. vi-46.

16 Alaska Health Survey Team, Alaska's Health, p. vi-46: "Tuberculosis is the most serious public health problem in Alaska." Also, p. vi-34: "The need to combine services of these two agencies (ANS and ADH), especially regards tuberculosis, is compelling ...Tuberculosis must be approached basically as an overall health problem of the Territory, and not as two separate problems, one of the native and another of the white population." The transfer of ANS to the Public Health Service from the BIA led to the renaming of the ANS to Alaska Native Health Service.

17 Penelope Cordes, "The Federal Government-Native American Relationship and the Indian Health Service in Alaska," Alaska Medicine, 32, 2 (April/May/June 1990): 70.

18 Fortuine, "Health Care and the Alaska Native," p. 20.

19 Alaska State Archives [hereafter ASA], RG 311, Series 43, Box 3, Board of Health, Board of Health Minutes, 1948-58, "Exhibit 7, Alaska Native Health Service," Discussion points related to transfer of ANS to ADH, 1955.

20 ASA, RG 311, Series 43, Box 3, Board of Health, Board of Health Minutes, 1948-58, "Exhibit 7, Alaska Native Health Service," "Progress Report on Parran Team Recommendations," and "Sanitation Aide Program."

21 National Archives, Pacific Alaska Region [hereafter NA, PAR], Anchorage, RG 513, Alaska Area Native Health Service, Program Correspondence, 1947-1979, Box 2, File 52.31, Telegram to SUD, Alaska Native Medical Centre, Anchorage from SUD, Mt. Edgecumbe Hospital 2 March 1975.

22 NA, PAR, RG 513, Alaska Area Native Health Service, Program Correspondence, 1947-1979, Box 2 File 54.25, Anchorage Daily Times, 28 November 1953 (news clippings).

23 NA, PAR, RG 513, Anchorage Daily Times, 29 November 1953.

24 Metcalf, Gumboot Determination, p. 35.

25 University of Alaska-Fairbanks, Oral history Archives, Tape H93-01-23, Gemma Joseph Gaudio interviewed by Illene Stein, 21 October 1980.

26 Vera Marvin, personal communication with author, 17 March 2004, Sitka, AK.

27 Judy Johnstone, personal communication with author, 18 March 2004, Sitka, AK.

28 Judy Johnstone, personal communication with author, 18 March 2004, Sitka, AK.

29 University of Alaska-Fairbanks, Oral History Archives, Tapes H96-16-01, H96-16-02 and H77-8, interview with Effie Graham. Also, Jean Frank, personal communication with author, 17 March 2004, Sitka, AK.

30 Corrine Brown, personal communication with author, 18 March 2004, Sitka, AK.

31 Marjorie Ward and Marlys Tedin, personal communication with author, 18 July 2003, Sitka, AK.

32 NA, PAR, RG 513, Alaska Area Native Health Service, Program Correspondence, 1947-1979, Box 3 File 56.20, "Training Programs."

33 Jean Frank, personal communication with author, 17 March 2004, Sitka, AK. Dorothy Thomsen, personal communication with author, 17 March 2004, Sitka, AK. 
34 University of Alaska-Fairbanks, Oral History Archives, Tape H89-30 Interview with Amos Alter by Dr. Walter Johnson, 10 June 1989.

35 University of Alaska-Fairbanks, Oral History Archives, Tape H89-30 Interview with Amos Alter by Dr. Walter Johnson, 10 June 1989. See also Alaska State Archives, RG 311, Series 43, Box 3, Board of Health, Board of Health Minutes, 1945-58, no file, "Sanitation Aide Program" Exhibit 8, Alaska Board of Health Agenda, 12-15 October 1955.

36 Philip Nice with Walter Johnson, The Alaska Health Aide Program: A Tradition of Helping Ourselves (Port Townsend, Wash.: Philip Nice, 1998) p. 15-16.

37 ASA, RG 311, Series 43, Box 3, Board of Health, Board of Health Minutes Alaska Board of Health Agenda, November 8-12, 1954, "Plan for Improving Environmental Health in the Native Communities in Alaska."

38 C. Richard Maundrell, "Indian Health: 1867-1940," (unpublished MA thesis, Queen's University, 1941) p. 10, 15, 39. Maundrell writes, "A questionnaire sent in 1933 to the Agents in the Territories showed that the evidence of non-pulmonary tuberculosis was very high evidence of low resistance ... the epidemic is much severer today in the north" (p. 39).

39 G. Graham-Cumming, "Health of the Original Canadians, 1867-1967," Medical Services Journal of Canada, 23, 2 (1967): 115-66, 141-42. Also, House of Commons Debates, 21 June 1951, Volume V, 1951, p. 4450 and 4453.

40 Maundrell, "Indian Health," p. 45.

41 Canada, Department of National Health and Welfare [hereafter DNHW], Annual report, Indian Health Services, 1949/1950, p. 80.

42 DNHW, Annual report, Indian Health Services, 1947/48, p. 41.

43 DNHW, "Indian and Northern Health Services," Canada's Health and Welfare, 16, 2 (1961), Supplement No. 38.

44 DNHW, Annual Report, Indian Health Services, 1945/46, p. 26.

45 Charles Camsell History Committee, The Camsell Mosaic: the Charles Camsell Hospital, 1945-1985 (Altona, MB: Friesen Printers, 1985), p. 43, 95, 98.

46 Charles Camsell History Committee, The Camsell Mosaic, p. 249.

47 In that year the Camsell Hospital became partially accountable to the Alberta provincial department of health under the new universal health care program in Canada, which was administered by the provinces. The impact on the Camsell was that it had to change its accounting practices to verify the costs of care of Indians in hospital for anything other than tuberculosis care.

48 Paul Martin, Minister of National Health and Welfare, "Canada's Indian Health Services," speech delivered in the radio series, Report from Parliament Hill, 29 March 1947. Transcription available in Claims and Historic Research Centre (Ottawa), File L. 14.

49 Laurie Meijer Drees, "Training Aboriginal Nurses: the Indian Health Service in northwestern Canada, 1939-1975" (unpublished manuscript in author's collection, 2005).

50 Kathleen Anderson Steinhauer, personal communication with author, 25 August 2004, Edmonton, AB.

51 Charles Camsell History Committee, The Camsell Mosaic, p. 162.

52 Charles Camsell History Committee, The Camsell Mosaic, p. 196-97.

53 Kathleen Anderson Steinhauer, personal communication with author, 25 August 2004, Edmonton, AB.

54 Steinhauer, 25 August 2004.

55 Canada, House of Commons Debates (6 June 1952, Volume III, 1952), p. 2988.

56 DNHW, Annual report, Indian Health Services, 1948/49, p. 108.

57 DNHW, Annual report, Indian Health Services, 1950/51, p. 65.

58 DNHW, Annual report, Indian Health Services, 1954/55, p. 78. 
59 Ethel Martens, "Culture and Communications-Training Indians and Eskimos as Community Health Workers," Canadian Journal of Public Health, 57, 11 (November 1966): 495, 501.

60 W. G. Brown, "Something new in training," Canadian Journal of Public Health, 57, 11 (November 1966): 535.

61 Alice K. Smith, "Indian and Eskimo health auxiliaries," in Roy J. Shephard and Sam Itoh, ed., Proceedings of the 3rd International Symposium on Circumpolar Health (Toronto: University of Toronto Press, 1974), p. 591.

62 Alice K. Smith, "Indian amd Eskimo," p. 592.

63 Young, Health Care and Cultural Change, p. 91. 